\title{
PENINGKATAN MOTIVASI BELAJAR SISWA MELALUI PEMBELAJARAN KOOPERATIF TIPE STAD PADA MATA PELAJARAN PKn KELAS V SDN JOMBANG 2 CIPUTAT SANTHI PERTIWI ${ }^{1}$
}

\author{
${ }^{1}$ Program studi PGSD, Fakultas Ilmu Pendidikan Universitas MH. Thamrin
}

\begin{abstract}
ABSTRAK
Penelitian ini bertujuan untuk mendeskripsikan pembelajaran kooperatif tipe STAD dalam peningkatan motivasi belajar siswa pada mata pelajaran PKn di SDn Jombang 2 Ciputat kelas V. Penelitian ini menggunakan penelitian tindakan kelas (PTK) yang dilaksanakan dalam dua siklus. Metode pengumpulan data yang digunakan dalam penelitian ini menggunakan metode kualitatif dan kuantitatif. Data yang diperoleh secara kualitatif adalah data observasi, data tentang efektivitas penerapan model pembelajaran kooperatif tipe STAD. data diperoleh kuantitatif adalah data tentang motivasi belajara siswa pada pembelajaran Pkn tentang mengenal sistem pemerintahan tingkat pusat. Hasil penelitian menunjukkan bahwa penerapan model pembelajaran kooperatif tipe STAD dapat meningkatkan motivasi belajar siswa yang meningkat, hal ini dilaksanakan dengan melalui tahapan - tahapan yaitu mengorientasi siswa kepada masalah, mengorganisasi siswa untuk belajar, penyelidikan baik secara individu maupun kelompok, mengembangkan dan menyajikan hasil karya, menganalisis dan mengevaluasi proses pemecahan masalah. Pada tahapan penyelidikan individu, dapat melatih siswa untuk mandiri dan bertanggung jawab pada suatu masalah dengan peranan guru yang selalu membimbing dan mengarahkan proses penyelidikan dengan baik, sementara itu keaktifan siswa semakin meningkat, siswa benar - benar melakukan pembelajaran secara langsung. Peningkatan ini hasil belajar siswa dengan menggunakan model pembelajaran kooperatif tipe STAD pada mata pelajaran Pkn kelas IV pada siklus II meningkat cukup signifikan dibandingkan pada siklus I, dimana bahwa jumlah siswa yang tuntas belajar pada siklus I mencapai $75 \%$ atau sekitar 15 orang dan yang belum tuntas belajar $25 \%$ atau sekitar 5 orang. Sedangkan pada siklus II mencapai 85\% atau sekitar 17 orang dan yang belum tuntas belajar $15 \%$ atau 3 orang. Ini membuktikan adanya peningkatan dari siklus I ke siklus II.
\end{abstract}

Kata Kunci: Model Pembelajaran Kooperatif Tipe STAD, Motivasi Belajar

\section{Pendahuluan}

Guru mengajar harus memiliki segudang metode atau strategi dalam pembelajaran, hal demikian sangat diperkukan dalam era globalsasi dan kemajuan teknologi yang semakin cepat hamper tak terkendali pada dewasa ini, dimana informasi dan komunikasi yang bergerak cepat seperti saat ini. Proses dan hasil pembelajaran Pkn terhadap siswa harus lebih dioptimalkan agar hasil dari perolehan nilainya dapat dilihat, adanya peningkatan motivasi siswa dalam belajar, dari adanya peningkatan prestasi belajar semakin baik dalam segala bidang mata pelajaran, khususnya bidang mata pelajaran Pkn mulai dari bidang pendidikan khusus sampai tingkat pergurauan tinggi buku dan berbagai media pembawa informasi lainnya yang dibuat tidak dalam bahasa asli memerlukan suatu proses penyampaian informasi dari bahasa sumber ke dalam media pembelajaran yang sesuai pada bahasa sasaran.

Tujuan pembelajaran dapat ditemukan dengan berbagai macam keadaan. Namun dalam pengelolaan kelas yang baik maupun kurang baik, tidak selamanya dilaksanakan, seperti tidak refresentatifnya guru pada situasi dan kondisi kelas untuk kegiatan belajar mengajar, seorang guru harus memiliki segudang teknik mengajar yang tujuan utamanya agar materi dapat tersampaikan secara maksimal sesuai dengan kurikulum pendidikan pemerintah, adaun yang dimaksud teknik penyajian pembelajaran adalah suatu pengetahuan tentang cara - cara mengajar yang akan dipergunakan guru. Oleh karena itu, peneliti menerapkan pembelajaran kooperatif tipe STAD.

Pengajaran terdapat berbagai macam strategi dan metode atau teknik pembelajaran mulai dari yang tradisional sampai pada perkembangan modern saat ini, pembelajaran yang peneliti akan terapkan adalah metode diskusi. Peneliti menerapkan proses belajar dan pembelajaran siswa nyaman dan siswa dapat mengimplementasikan ilmu, dikelas maupun dimana ia tinggal tentunya, selain itu siswa dapat termotivasi mengikuti proses belajar dan pembelajaran. Kemampuan guru dalam menentukan metode yang sesuai dengan tujuan dan materi pelajaran juga merupakan kunci keberhasilan dalam meningkatkan motivasi belajar siswa. Tuntutan tersebut harus dimiliki oleh seorang guru ketika melakukan proses pembelajaran, khususnya pembelajaran matematika. Hal tersebut sejalan dengan tuntutan kurikulum saat ini yang sangat memperhatikan metode pembelajaran yang akan digunakan oleh guru.

Peserta didik pada masa usia sekolah dasar sebagai masa kanak-kanak yang berlangsung dari usia 6 tahun hingga 12 tahun. Menurut para ahli psikologi, yang juga harus diperhatikan dalam pendidikan adalah menyelesaikan tugas perkembangan pada tahap yang sedang berlangsung. Salah satu tugas perkembangan anak usia sekolah dasar adalah belajar, bergaul dan bersahabat dengan anak-anak sebayanya, dan bekerja dalam kelompok. Tahap perkembangan ini harus bisa dimiliki anak usia SD agar perkembangan tahap berikutnya tidak mengalami gangguan yang mengakibatkan perkembangan sosial yang menyimpang. Akan tetapi, pada kenyataannya banyak dijumpai 
pembelajaran di SD/MI masih jauh dari harapan. Pembelajaran di SD/MI masih banyak menggunakan pembelajaran konvensional yang hanya terpusat pada guru semata (teacher centered).

Pembelajaran ini masih sering diterapkan oleh guru dengan alasan pembelajaran ini adalah yang paling praktis dan tidak menyita waktu yang banyak sehingga menyebabkan sedikit tuntutan aktifitas belajar dari siswa. Dalam proses pembelajaran masih sering dijumpai adanya kecenderungan peserta didik yang menyerah meskipun mereka sebenarnya masih bingung tentang materi yang disampaikan. Ditambah lagi dalam praktik belajar, kepribadian (kecerdasan emosional) terabaikan hanya mengutamakan aspek akademik (kecerdasan intelektual) semata yang dipentingkan.

Proses pembelajaran seperti yang diungkapkan tersebut sangat tidak diharapkan. Konsep-konsep matematika lebih banyak langsung diberikan kepada siswa tanpa adanya proses yang bermakna yang melibatkan siswa untuk pengalaman dalam belajar yang nantinya akan berdampak pada hasil akademik yang rendah maupun kepribadian yang kurang baik. Untuk mencapai tujuan pembelajaran, diperlukan strategi, pendekatan, metode, serta teknik tertentu. Dengan kata lain, keberhasilan proses pembelajaran juga bergantung pada bagaimana suatu bahan ajar disampaikan.

Salah satu model pembelajaran yang dapat mengaktifkan siswa adalah pembelajaran kooperatif. Terdapat beberapa tipe dalam pembelajaran kooperatif, salah satunya adalah tipe Student Teams Achievement Divisions (STAD). STAD merupakan salah satu model pembelajaran kooperatif yang paling sederhana, dan merupakan model pembelajaran kooperatif yang paling baik untuk permulaan bagi para guru yang baru menggunakan pendekatan kooperatif. Pada tipe ini terdapat beberapa tahap yang harus dilalui selama proses pembelajaran. Tahap awal, siswa belajar dalam suatu kelompok dan diberikan suatu materi yang dirancang sebelumnya oleh guru. Setelah itu siswa bersaing dalam turnamen untuk mendapatkan penghargaan kelompok. Selain itu terdapat kompetisi antar kelompok yang dikemas dalam suatu permainan agar pembelajaran tidak membosankan. Pembelajaran kooperatif tipe STAD juga dapat membuat siswa aktif dan termotivasi mencari penyelesaian masalah dan mengkomunikasikan pengetahuan yang dimilikinya kepada siswa yang lain, sehingga masing-masing siswa lebih menguasai materi. Dalam pembelajaran tipe STAD, guru berkeliling untuk membimbing siswa saat belajar kelompok. Hal ini memungkinkan siswa untuk berinteraksi dengan guru dan diharapkan tidak ada ketakutan bagi siswa untuk bertanya atau berpendapat kepada guru. Pembaharuan pembelajaran yang sedang banyak diupayakan melahirkan model-model pembelajaran, yang diyakini merupakan solusi bagi masalah pembelajaran. Pembelajaran yang berbasis pada teori Kontruktivisme telah melahirkan model pembelajaran kooperatif atau cooperative learning.

Pembelajaran Kooperatif memberi tekanan pada aktivitas belajar secara kooperatif dalam kelompok-kelompok kecil. Namun menurut Roger dan David dalam Anita Lie (2002: 30) mengatakan tidak semua kerja kelompok dapat dianggap cooperative learning, ada lima unsur yang harus diterapkan yaitu saling ketergantungan positif, tanggung jawab perseorangan, tatap muka,komunikasi antar anggota, dan evaluasi proses kelompok. Pendekatan dalam model pembelajaran kooperatif yang dapat digunakan guru diantaranya adalah tipe belajar STAD (Student Team Achievement Division), tipe Jigsaw, tipe investigasi kelompok, dan tipe pendekatan struktural. Guru dapat menggunakan salah satu pendekatan tersebut sesuai dengan tujuan yang ingin dicapai.

STAD merupakan pendekatan pembelajaran kooperatif yang paling sederhana. Guru yang pertama kali akan menggunakan model pembelajaran kooperatif hendaknya menggunakan tipeSTAD (Slavin, 1995: 71). Keistimewaan dalam STAD adalah bekerjasama dalam kelompok belajar. Pelaksanaannya menerapkan strategi kelompok belajar dengan anggota $4-5$ siswa dengan memperhatikan perbedaan individu seperti tingkat kemampuan, jenis kelamin, kecepatan belajar, sosial budaya atau latar belakang yang berbeda. Model Pembelajaran Kooperatif Tipe STAD Salah satu model pembelajaran yang dapat mengakomodasi kepentingan untuk mengkolaborasikan pengembangan diri di dalam proses pembelajaran adalah model pembelajaran kooperatif (cooperative learning). Ide penting dalam pembelajaran kooperatif adalah membelajarkan kepada siswa keterampilan kerjasama dan kolaborasi. Keterampilan ini sangat penting bagi siswa, karena pada dunia kerja sebagian besar dilakukan secara kelompok (Dewi Tisnawati, 2008:37). Pembelajaran kooperatif tipe STAD tumbuh dari suatu tradisi pendidikan yang menekankan berpikir dan latihan bertindak demokratis, pembelajaran aktif, perilaku kooperatif, dan menghormati perbedaan dalam masyarakat multibudaya. Dalam pelaksanaannya pembelajaran kooperatifdapat merubah peran guru dari peran terpusat pada guru ke peran pengelola aktivitas kelompok kecil. Sehingga dengan demikian peran guru yang selama ini monoton akan berkurang dan siswa akan semakin terlatih untuk menyelesaikan berbagai permasalahan, bahkan permasalahan yang dianggap sulit sekalipun 


\section{Kajian Literatur}

Motivasi Belajar

Menurut Whittaker yang dikutip alisuf sabri (1993:61) motivasi adalah suatu istilah yang sifatnya luas yang digunakan dalam psikologi yang meliputi kondisi-kondisi atau keadaan internal yang mengaktifkan atau memberi kekuatan pada organisme dan mengarahkan tingkah laku organisme mencapai tujuan. Sedangkan menurut Winkel motivasi adalah motif yang sudah menjadi aktif pada saat-saat melakukan percobaan, sedangkan motif sudah ada dalam diri seseorang jauh sebelum orang itu melakukan suatu perbuatan. Motivasi adalah segala daya yang mendorong seseorang untuk melakukan sesuatu.

Dalam psikologi motivasi diartikan sebagai suatu kekuatan yang terdapat dalam diri manusia yang dapat mempengaruhi tingkah lakunya untuk melakukan kegiatan. Sedangkan menurut Abu Ahmadidan Widodo Supriyono motivasi sebagai faktor inner (batin) berfungsi menimbulkan, mendasari dan mengarahkan perbuatan belajar. "Dalam kegiatan belajar, motivasi dapat dikatakan sebagai keseluruhan daya penggerak di dalam diri siswa yang menimbulkan kegiatan belajar, yang menjamin kelangsungan kegiatan belajar dan yang memberikan arah kegiatan belajar sehingga tujuan yang dikehendaki oleh subyek belajar itu dapat tercapai". Sesuai dengan pengertian motivasi yang dijelaskan di atas, bahwa tidak perlu dipertanyakan lagi pentingnya motivasi bagi siswa dalam belajar. Di dalam kenyataan motivasi belajar tidak selalu timbul dalam diri siswa. Ada sebagian siswa yang mempunyai motivasi tinggi namun ada juga yang rendah motivasinya. Oleh karena itu seorang guru harus bisa membangkitkan motivasi yang terdapat dalam diri siswa agar dapat mencapai tujuan belajar. Bagi siswa yang sudah mempunyai motivasi, guru bertugas untuk meningkatkan motivasinya, jika guru dapat membangun motivasi siswa terhadap pelajaran yang diajarkan, diharapkan seterusnya siswa akan meminati pelajaran tersebut.

Keberhasilan belajar siswa dipengaruhi oleh faktor dari dalam dan dari luar siswa. Faktor-faktor dari dalam mencakup kecerdasan, motivasi, perasaan butuh dan sebagainya. Sedanglan faktor dari luar seperti fasilitas belajar, cara guru mengajar, pemberian umpan balik, pujian, hukuman, dan sebagainya. Motivasi yang berasal dari dalam individu disebut motivasi instrinsik dan motivasi yang berasal dari luar individu disebut motivasi ekstrinsik. Guru dapat meningkatkan motivasi intrinsik dalam pembelajaran di ruang kelas dengan cara membangkitkan siswa agar memiliki perhatian dan keinginan dalam belajar suatu materi, dan menunjukkannya dengan rasa kepuasan dan rasa ingin tahu tentang materi yang dipelajarinya. (Slavin, 2008: 346).

Herry Sukarman (2003: 21) menjelaskan bahwa ada beberapa tindakan yang dapat memotivasi siswa, antara lain Memberi angka, Hadiah atau penghargaan, Menumbuhkan rasa sukses, dan Kerjasama. Siswa yang termotivasi untuk belajar sesuatu akan menggunakan proses kognitif yang lebih tinggi dalam mempelajari materi itu, sehingga siswa akan menyerap dan mengendapkan materi itu dengan lebih baik (Alexander \& Jetton, 1996; Graham \& Golan, 1991; Harp \& Mayer, 1997 ) dalam Slavin (2008: 328).

Faktor-faktor pembentuk motivasi belajar menurut Haris Mudjiman (2006: 73) adalah: Mengetahui kompetensikompetensi yang telah dimiliki, Mengetahui kebutuhan dirinya, Mengetahui kemampuan untuk mencapainya, dan rasa senang dalam belajar. Sumber utama munculnya motivasi menurut Gagne and Driscoll (1989: 64-66) adalah rasa ingin tahu (curiosity), keinginan berprestasi (achievement), dan rasa percaya diri (self-efficacy). Rasa ingin tahu dapat dibangun dari stimulus pada hal-hal yang baru, kompleks, dan hal-hal yang tidak biasa. Keinginan berprestasi sebagai sumber munculnya motivasi, karena ada keinginan untuk mencapai sesuatu, menguasai atau mengontrol sesuatu, dan untuk menghasilkan sesuatu. Sedangkan rasa percaya diri merupakan keyakinan tentang keterampilan untuk mencapai sukses atau untuk mampu berbuat sesuatu dan menghindari kegagalan.

Teknik mengajar untuk membangkitkan motivasi belajar menurut Haris Mudjiman (2006: 88-94) adalah Menumbuhkan rasa tahu kegunaan belajar, Menumbuhkan rasa butuh belajar, Menumbuhkan rasa mampu belajar,Menumbuhkan rasa senang belajar, Menumbuhkan kemampuan belajar, dan Menumbuhkan kemampuan menilai hasil belajar.

\section{Model Pembelajaran Kooperatif}

Model Pembelajaran kooperatif bertitik tolak dari pedagogi John Dewey (dalam Ibrahim, et.al. 2000: 13) yang mengharuskan guru menciptakan di dalam lingkungan belajarnya suatu sistem sosial y ang dicirikan dengan prosedur demokrasi dan proses ilmiah. Setelah itu, Herbert Thelan (dalam Ibrahim, et.al. 2000: 13) mengembangkan prosedur untuk membantu siswa bekerja dalam kelompok, yang menjadi dasar konseptual pengembangan pembelajaran ooperatif masa sekarang.

Siswa yang bekerja dalam situasi pembelajaran kooperatif didorong untuk bekerjasama pada tugas, dan mereka mengkoordinasikan usahanya untuk menyelesaikan tugasnya. Dalam penerapannya setiap individu saling tergantung satu sama lain untuk mencapai penghargaan bersama. Mereka akan berbagi penghargaan bila mereka berhasil sebagai kelompok. Pembelajaran kooperatif dapat mencapai hasil yang maksimal, bila menerapkan empat unsur dasar model pembelajaran kooperatif. (Nurhadi,dkk., 2003: 60). Empat unsur dasar pembelajaran kooperatif adalah Saling 
ketergantungan positif, Interaksi tatap muka, Akuntabilitas individual, dan Keterampilan menjalin hubungan antar pribadi.

\section{Model Pembelajaran Kooperatif Tipe STAD}

Menurut Rusman (2012:74) STAD merupakan salah satu tipe kooperatif yang menekankan pada adanya aktivitas dan interaksi diantara siswa untuk saling memotivasi dan saling membantu dalam menguasai materi pelajaran guna mencapai prestasi yang maksimal. Slavin (2008:141) berpendapat pembelajaran STAD merupakan tipe yang digunakan secara terstruktur. Model pembelajaran kooperatif tipe STAD merupakan model yang terdapatdalam pembelajaran kooperatif yang paling tua dan palingbanyak digunakan dalam penelitian pendidikan, termasuk juga dalam penyampaian materi dikelas. Anita Lie (2002:37) STAD didefinisikan salah satu bentuk dari pembelajaran kooperatif yang menggunakan kuis-kuis individual pada tiap akhir pelajaran. Sedangkan pembelajaran kooperatif menurut Hilda Karli dan Oditha R. Hutabarat adalah pendekatan pembelajaran yang memaksimalkan kondisi belajar untuk mencapai tujuan belajar.

Dari penjelasan di atas dapat diambil kesimpulan umum bahwa metode STAD adalah cara untuk mencapai tujuan dengan penggunaan kelompok kecil siswa untuk bekerjasama dalam belajar yang pada akhir pelajaran digunakan kuiskuis individual. Pelaksanaan prosedur model cooperative learning tipe STAD dengan benar akan memungkinkan pendidik mengelola kelas dengan lebih baik. Tujuan penting daripembelajaran kooperatif, meliputi : Hasil belajar akademik, Penerimaan terhadap perbedaan individu, dan Pengembangan Keterampilan Sosial. Dalam pengajaran kooperatif diperlukan tugas perencanaan dan keputusan yang dibutuhkan oleh guru, misalnya : memilih pendekatan yang tepat, memilih materi yang sesuai, pemben tukan kelompok siswa, menyiapkan LKS atau panduan belajar siswa, mengenalkan siswa kepada tugas dan perannya dalam kelompok, merencanakan waktu dan tempat duduk yang akan digunakan.

Pentingnya pembelajaran kooperatif menurut Nurhadi, dkk (2003: 62 - 63) diantaranya untuk memudahkan siswa melakukan penyesuaian sosial, meningkatkan keterampilan hidup bergotong royong, meningkatkan motivasi belajar intrinsik, dan meningkatkan sikap positif terhadap belajar dan pengalaman belajar.

Langkah - langkah pembelajaran koperatif Tipe STAD

Langkah - langkah pembelajaran kooperatif student teams achievement Divisions (STAD), sebagai berikut :

1. Membentuk kelompok yang anggotanya 4 siswa secara heterogen (campuran menurut presentasi)

2. Guru memberikan penjelasan tentang suatu materi

3. Guru memberikan tugas kepada kelompok untuk dikerjakan oleh anggota - anggota kelompok.

4. Anggota kelompok yang mengerti tentang materi menjelaskan materi kepada anggota yang lain dalam kelompok itu sendiri sampai anggota yang lain mengerti.

5. Guru memberi kuis atau pertanyaan kepada seluruh siswa.

6. Pada saat menjawab kuis tidak ada boleh kerjasama

7. Guru memberi evaluasi

8. Kesimpulan. (http:fatoniPGSD.wordpress.com)

Untuk mempermudah pelaksanaan pembelajaran kooperatif student teams achievements divisions (STAD), berikut penulis sajikan dalam bentuk tabel :

\begin{tabular}{|c|c|l|}
\hline No & Langkah & \multicolumn{1}{|c|}{ Kegiatan } \\
\hline 1 & I & $\begin{array}{l}\text { Guru menyampaikan materi pembelajaran ke siswa secara klasikal (paling sering } \\
\text { menggunakan model pembelajaran langsung). }\end{array}$ \\
\hline 2 & II & $\begin{array}{l}\text { Guru membagi siswa ke dalam beberapa kelompok (setiap kelompok terdiri dari 4 - 6 } \\
\text { siswa yang heterogenm baik dari segi kemampuan, agama, jenis kelamin, atau lainnya) }\end{array}$ \\
\hline 3 & III & $\begin{array}{l}\text { Dilanjutkan diskusi kelompok untuk penguat materi (saling bantu membantu untuk } \\
\text { memperdalam materi yang sudah diberikan) }\end{array}$ \\
\hline 4 & IV & $\begin{array}{l}\text { Guru memberikan tes individual, masing - masing mengerjakan tes tanpa boleh saling } \\
\text { bantu membantu diantara anggota kelompok. }\end{array}$ \\
\hline 5 & V & $\begin{array}{l}\text { Guru memberi penghargaan pada kelompok berdasarkan perolehan nilai peningkatan } \\
\text { individu dari skor dasar ke skor kuis. }\end{array}$ \\
\hline
\end{tabular}

Pembelajaran PKn di SD / MI

Dengan memahami akan luasnya materi dalam pembelajaran pendidikan kewarganegaraan di sekolah, guru sebagai salah satu unsur pendidik diharapkan mampu melaksanakan tugas professionalnya adalah memahami bagaimana peserta didik belajar dan bagaimana mengorgansasikan proses pembelajaran yang mampu mengembangkan kemampuan dan membentuk watak peserta didik, serta memahami tentang siswa belajar. Perolehan informasi guru dapat terjadi dari kegiatan membaca, mendengarkan penjelasan guru mengenai materi yang diajarkan atau mendengarkan/melihat audiovisual dan lain - lain. 
Belajar sebagai proses manusiawi memiliki kedudukan dan peran penting, baik dalam kehidupan masyarakat tradisonal maupun modern. Pentingnya proses belajra dapat dipahami dari traditional / local wisdom, filsafat, temuan penelitian dan teori tentang belajar. Traditional /local wisdom adalah ungkapan verbal dalam bentuk frasa, peribahasa, adagium, maksim, kata mutiara, petatah - petitih atau puisi yang mengandung makna eksplisit atau implisit tentang pentingnya belajar dalam kehidupan manusia. Pkn merupakan materi yang focus pada pembentukan diri yang beragam baik dari segi agama sosio-kultural, bahasa, usia dan suku bangsa, untuk menjadi kewarganegara yang cerdas, terampil dan berkarakter. Materi Pkn bertujuan mengembangkan kemampuan - kemampuan peserta didik sebagai berikut :

1. Berfikir secara kritis, rasional, dan kreatif.

2. Berfartisifasi secara bermutu dan bertanggungjawa dan bertindak secara cerdas dalam kegiatan bermasyarakatan, berbangsa dan bernegara.

3. Berkembang secara demokratis dan positif thingking dan membentuk berdasarkan karakter - karakter masyarakat Indonesia agar dapat hidup bersama, bekerjasama dengan bangsa - bangsa lainnya.

4. Berintegrasi dengan bangsa - bangsa lain dalam percaturan dunia secara langsung atau tidak langsung degan teknologi informasi dan komunikasi.( Ine kusuma aryani, 2003 : 18)

\section{Metode Penelitian}

Dalam melaksanakan suatu penelitian diperlukan cara kerja yang berencana agar daya yang dikumpulkan dapat mencapai maksud dan tujuan dari penelitian. Menurut winarno surakhmad, "metode merupakan cara utama yang dipergunaan untuk mencapai tujuan, misalnya untuk menguji serangkaian hipotesis dengan mempergunakan teknik serta alat - alat tertentu, cara utama ini dipergunakan setelah penyidik memperhitungkan kewajaran, ditinjau dari penyelidikan dalam arti luas, yang biasanya perlu diperjelas lebih ekspilit dalam setiap penyelidikan". (winarno surarkhmad, 1985:131). Sukmadinata, mengungkapkan bahwa metode penelitian merupakan rangkaian cara atau kegiatan pelaksanaan penelitian yang didasari oleh asumsi-asumsi dasar, pandangan-pandangan filosofis, dan idiologis, pertanyaan dan isu - isu yang dihadapi. Pemilihan dan penentuan metode tidak dapat dipisahkan dari tujuan dan perumusan masalah, kalau permasalahannya hanya difokuskan pada satu variable atau aspek dan tujuannya ingin mendapakan deskripsi dari variable atau aspek tersebut, maka metodenya adalah metode deskriptif atau survey. Jika terdapat dua variable dan ingin mengetahui hubungan diantara variable tersebut, maka metodenya adalah metode korelasional atau komparatf. Jelasnya, bahwa pemilihan metode sangat tergantung kepada tujuan dan rumusan masalah yang sudah difokuskan pada bagian sebelumnya. (maifalinda fatra, 2010:79)..

Metode penelitian yang digunakan dalam penelitian tindakan kelas (Classroom Action Research), bertujuan untuk memecahkan masalah - masalah melalui penerapan langsung di kelas atau tempat kerja. Sedangkan, menurut Prof Suhardjono mengatakan mengataan bahwa penelitian tindakan kelas merupakan bagian dari penelitian tindakan yang dapat dipandang sebagai tindak lanjut dari penelitian deskriptif maupun eksperimen. Pada penelitian tindakan kelas bukan lagi mengetes sebuah perlakuan tetapi sudah mempunyai keyakinan akan ampuhnya sesuatu perlakuan. (suharsimi arikunto, 2006 : 56). Berdasarkan pendapat para ahli, dapat disimpulkan bahwa metode penelitian adalah alat yang dapat dipergunakan untuk melaksanakan dan mencapai suatu penelitian yang disusun secara teratur dan logis yang dituangkan dalam suatu rencana kegiatan penelitian.

Proses daur ulang kegiatan dalam penelitian tindakan, menurut Kemmis \& Taggart (1984:7) hakekatnya berupa siklussiklus atau untaian-untaian dengan satu siklus terdiri dari empat komponen yakni

1) Perencanaan (planning) ialah tindakan yang akan dilakukan di konsep dan ditentukan langkah-langkahnya.

2) Tindakan (action) adalah Tindakan yang digunakan adalah tindakan yang sengaja dilakukan dan terkontrol.

3) Pengamatan (observation) ialah pengamatan berfungsi untuk mendokumentasi efek dari tindakan.

4) Refleksi (reflection) adalah menghubungkan tindakan yang telah dilakukan,seperti mengingat tindakan sebelumnya dengan peristiwa yang telah dicatat oleh pengamat.

Rancangan Siklus Penelitian.

Untuk mempermudah dalam memahami rencana tindakan secara keseluruhan dan untuk memberikan panduan bagi penulis, maka penulis perlu menampilkan metode penelitian tindakan yang akan dilaksanakan, diadaptasi dari model penelitian tindakan model John Elliot. Penelitian tindakan kelas dilaksanakan dalam 2 siklus (tiap siklus 2 kali tatap muka/pertemuan). Prosedur penelitian dapat digambarkan dengan skema sebagai berikut.

Bagan Prosedur Penelitian Model John Elliot

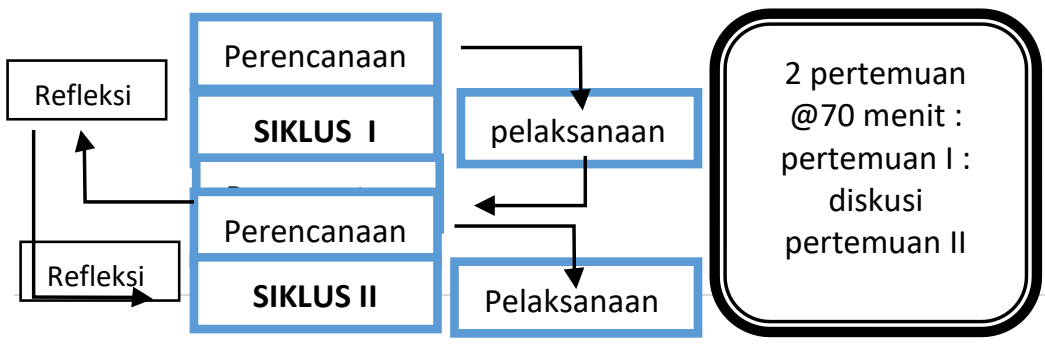



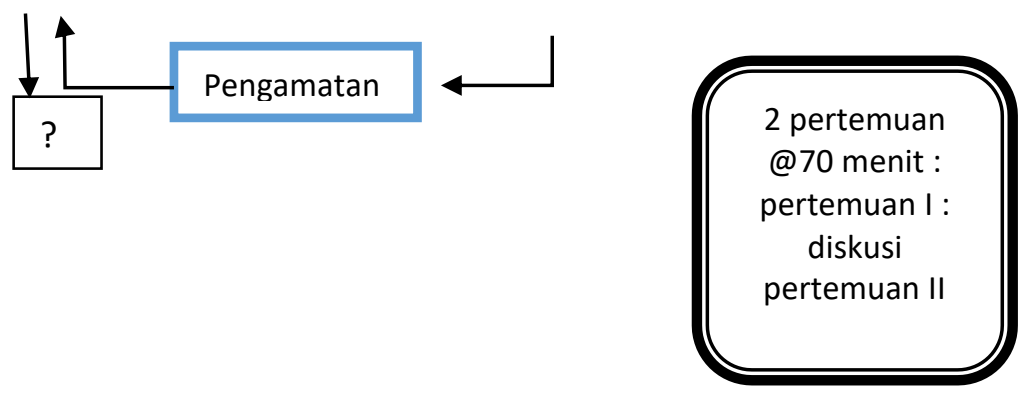

\section{Hasil Penelitian Dan Pembahasan}

Setelah dilakukannya penelitian tinakan kelas yaitu dengan menetapkan pembelajaran kooperatiftipe STAD tentang motivasi belajar siswa pada masa pelajaran PKn Kelas IV (empat), hasil belajarv siswa mengalami peningkatan khususnya pada isi naskah drama. Pada siklus I, terjadi peningkatan nilai rata-rata dari pretest yatu sebesar 33 menjadi 66 nilai rata-rata dari pretest. Hal ini mungkin disebabkan siswa masih belum mengerti bagaimana langkah-langkah pembelajaran kooperatif tipe STAD yang baru mereka dapatkan, selama proses pembelajaran guru bidang studinya belum pernah menerapkan model pembelajaran seperti ini. Sehingga siswa merasa kebingungan dan sulit untuk beradaptasi dengan proses pembelajaran baru.

Pada hasil belajar berupa kognitif (pemahaman) pada siklus I jumlah siswa yang mencapai KKM 60 yaitu 15 siswa, sedangkan jumlah siswa yang tidak mencapai KKM 60 yaitu 5 siswa. Ada kemungkinan siswa yang belum mencapai nilai KKM ini disebabkan belum bias menangkap atau menerima dengan baik model atau model pembelajaran yang diterapkan oleh guru. Skor N-Gain yang didapatkan pada siklus I sebesar 0,33 dengan kategori sedang.

Pada siklus II, siswa yang mencapai nilai KKM 60 ada 17 siswa, sedangkan yang belum mencapai nilai KKM 60 ada 3 siswa. Skor N-Gain dari siklus I ke siklus II menunjukkan bahwa terjadi peningkatan hasil belajar dengan skor NGain pada siklus I sebesar 0,33 menjadi 0,37 pada siklus II.

Pencapaian hasil belajar siswa dipengaruhi oleh model pembelajaran yang diterapkan selama proses pembelajaran dengan menggunakan pembelajaran kooperatif tipe STAD baik secara individu maupun kelompok. Proses pembelajaran ini dapat berinteraksi dengan siswa lainnya, guru dan sumber belajar. Sumber belajar yang digunakan adalah buku paket pada mata pelajaran PKn.

Kegiatan siswa pada siklus I telah menunjjukan rata - rata keterlaksaannya langkah - langkah model pembelajaran kooperatif tipe STAD dengan kategori sedang sebesar 0,33. Hal ini menunjukkan bahwa pemberian tindakan dengan menggunakan pembelajaran kooperatif tipe STAD memberikan kesempatan kepada siswa untuk terlibat langsung selama proses pembelajaran. Akan tetapi, siswa masih kurang memunculkan langkah - langkah merumuskan masalah dan merumuskan hipotesis. Pengungkapan pertanyaan siswa pada suatu masalah masih bersifat konsep dasar dan bukan merupakan pengembangan konsep. Siswa belum terlatih dalam kemandirian belajar atau selalu mengandalkan guru untuk mengungkapkan suatu konsep dari suatu permasalahan.

Kegiatan guru telah konsisten dalam menerapkan RPP selama pembelajaran. Dari data pengamatan, sebagian besar siswa telah berperan aktif selama proses belajar mengajar berlangsung. Hasil dari siklus I menunjukkan jumlah siswa yang mencapai nilai KKM 60 belum memenuhi indicator keberhasilan yaitu $85 \%$ dan hanya mencapai $75 \%$ sehingga penelitian ini akan dilanjutkan ke siklus II. Setelah dilanjutkan ke siklus II yaitu dengan berbagai tindakan perbaikan yang dilaksanakan pada siklus II ternyata hasil belajarnya mengalami peningkatan. Nilai pretest 33,00 dan posttest 70,00. Siswa yang mencapai nilai KKM 60 pada siklus II ada 17 siswa, sedangkan yang belum mencapai nilai KKM 60 ada 3 siswa. Skor N-Gain dari siklus I ke siklus II menunjukkan bahwa terjadi peningkatan hasil belajar dengan skor N-Gain pada siklus I sebesar 0,33 menjadi 0,37 pada siklus II. Hal ini membuktikan bahwa siswa mampu mengembangkan proses berfikir kritis mereka sehingga mereka bias berkreasi dan dapat memecahkan masalah secara sistematis dan logis.

Peningkatan pada siklus II ditunjukkan pula dengan data observasi siswa yang menunjukkan telah terlaksanakannya langkah - langkah dengan pembelajaran kooperatif tipe STAD diantaranya yaitu menyadari masalah, merumuskan masalah, merumuskan hipotesis, menguji hipotesis dan menentukan pilihan penyelesaian. Sehingga, dihasilkan rata rata siswa yang memunculkan semua langkah - langkah dengan pembelajaran kooperatif tipe STAD dari siklus I dan siklus II yaitu dari kategori buruk $(41,25 \%)$ menjadi sangat baik $(82,76 \%)$. Pada siklus II, jumlah siswa yang memiliki nilai di atas KKM 65 adalah $85 \%$ presntase tersebut telah memadai nilai indicator keberhasilan yaitu $85 \%$ sehingga pemberian tindakan pada proses pembelajaran siklus II bias dihentikan. 


\section{Pembahasan}

Penerapan pembelajaran dnegan pembelajaran kooperatif tipe STAD yang berkelanjutan dalam dua siklus telah menunjukkan peningkatan pada setiap aspek langkah - langkah pembelajaran dengan pembelajaran kooperatif tipe STAD . jika dianalisis setiap aspeknya, maka tiap - tiap aspek telah menunjukkan peningkatan dari siklus I ke siklus II , dan pada siklus II semua aspek telah menunjuukan kategori baik. Hal ini berarti siswa telah mengalami perubahan dalam belajar dan memahami suatu konsep dengan baik pula. Selain itu, berdasarkan hasil wawancara siswa telah memberikan tanggapan- tanggapan yang positif terhadap pembelajaran yang diterapkan karena siswa diberikan pembelajaran secara langsung dan atktif serta diberi kesempatan untuk mengungkapkan gagasan - gagasan baru dalam menyajikan hasil karya penyelesaian masalah selama proses belajar mengajar yang berlangsung di kelas. Siswa juga tidak merasa penasaran dengan apa yang mereka lihat, dengar dan pelajari tentang pemahaman isi naskah drama. Siswa merasa lebih menyukai model pembelajaran ini dan lebih mudah memahami materi pelajaran.

Dari penjelasan - penjelasan di atas, menunjukkan bahwa pembelajaran kooperatif tipe STAD memberikan kesempatan kepada siswa untuk terlibat langsung, aktif, mandiri, kreatif, dan berfikir kritis selama pembelajaran serta pembentukan suatu konsep yang nyata dan sistematis. Sehingga pembelajaran mencapai tujuan pembelajaran yang ditetapkan dan meningkatkan hasil belajar siswa. Oleh karena itu, melalui pembelajaran kooperatif tipe STAD dapat meningkatkan motivasi belajar siswa pada mata pelajaran PKn kelas V (Lima) SDn 2 Jombang-Ciputat.

\section{Kesimpulan}

Peningkatan hasil belajar siswa dengan menggunakan model pembelajaran kooperatid tipe STAD pada mata pelajaran PKn kelas V (lima) pada siklus II meningkat cukup sigifikan dibandingkan pada siklus I, dimana bahwa jumlah siswa yang tuntas belajar pada siklus I mencapai $75 \%$ atau sekitar 15 orang dan yang belum tuntas belajar 25\% atau sekitar 5 orang. Sedangkan pada siklus II mencapai $85 \%$ atau sekitar 17 orang dan yang belum tuntas belajar $15 \%$ atau sekitar 3 orang. Ini membuktikan adanya peningkatan dari siklus I ke siklus II. Dengan demikian, dapat dikatakan bahwa penerapan model pembelajaran kooperatif tipe STAD pada materi tentang pemerintahan di Indonesia di kelas V (lima) SDn 2 Jombang - Ciputat dapat meningkatkan hasil belajar siswa, yakni meningkat sampai $10 \%$.

\section{Saran}

Berdasarkan kesimpulan dan implikasi penelitian yang telah dikemukakan di atas, maka untuk meningkatan motivasi belajar siswa melalui pembelajaran kooperatif tipe STAD pada mata pelajaran PKn kelas V (lima) SDn 2 Jombang Ciputat, sebaiknya dilaksanakan dengan melalui tahapan - tahapan secara sistematis yaitu mengorientasi siswa kepada masalah, mengorganisasi siswa untuk belajar, penyelidikan baik secara individu maupun kelompok , mengembangkan dan menyajikan hasil karya, menganalisis dan mengevaluasi proses pemecahan masalah. Dimana pada tahapan tiga yaitu penyelidikan secara individu, dapat melatih siswa untuk mandiri dan bertanggung jawab pada suatu masalah dengan peranan guru yang selalu membimbing dan mengarahkan proses penyelidikan dengan baik, sementara itu keaktifan siswa semakin meningkat, siswa benar - benar kemampuan siswa dalam memahami materi pada mata pelajaran PKn. 


\section{Daftar Pustaka}

Aryani, Ine Kusuma dan Markum Susatim. 2003 Pendidikan kewarganegaraan (Pkn) berbasis Nilai (Jakarta : Depdiknas)

Fatoni. Langkah - langkah dalam model pembelajaran inovatif (online) (http:fatoniPGSD.wordpress.com). diakses tanggal 7 may 2011

Gagne, Robert M and Driscol, Marcy Perkins. 1989. Essentials of Learning for Intruction. (New Jersey:Prentice-hall.inc)

Ibrahim, M, et al. 2000. Pembelajaran Kooperatif. Surabaya: University Press

Lie, Anita,. 2002. Cooperative learning. Mempraktikkan cooperative learning di ruang - ruang kelas (Jakarta: Gramedia Widiasarana Indonesia)

Kemmis dan Taggart, 1998, The Action Research Planner, $3^{\text {rd }}$ ed. (Victoria : Deaklin University).

Mudjiman, Haris,. 2006. Belajar Mandiri= Self Motivated Learning). (solo:LPP dan UNS Press)

Nurhadi, dkk. 2003. Pembelajaran Kontekstual dan Penerapannya dalam KBK. (Malang: Universitas Negeri Malang.)

Rusman. 2012. Model-Model Pembelajaran: Mengembangkan Profesionalisme Guru. (Jakarta: Rajawali Pers).

Sabri, Alisuf. 1993 Pengantar Psikologi Umum dan Perkembangan. (Jakarta: Pedoman Ilmu Jaya).

Slavin, Robert E. 1995. Cooperative Learning, Theory, Research, and Practice. (Needham Heights, Massachusetts:Allyn and Bacon.)

Slavin, Robert E. 2008. Cooperative learning : Teori, Riset dan Praktek. (Bandung : Nusa Media)

Surakhmad, Winarno. 1985. Pengantar Penelitian Ilmiah Dasar.,metode teknik.(Bandung:Tarsito,)

Sukarman, Herry. 2003. Dasar - dasar didaktik dan penerapannya dalam pembelajaran (Jakarta: Direktorat Tenaga KEpendidikan)

Tisnawati, Dewi. "Penerapan Model Cooperative Learning Tipe STAD dalam

Pembelajaran Biologi untuk Meningkatkan Prestasi Belajar Siswa Kelas X

MAN Model Palu". (Jurnal Derap Pendidikan Vol. 2, No. 3, 2008). 